KRYVYZYUK LEONID,

Scientific Center of the Land Forces Academy named after P. Sahaydachny (Lviv, Ukraine)

e-mail: leonid.krivizuk@gmail.com,ORCID 0000-0001-9094-4061

\title{
STALINGRAD STRATEGIC OFFENSIVE OPERATION (19.11.1942 - 02.02.1943): FACTORS OF SUCCESS OF TANK FOR SURROUNDING AND DESTRUCTION OF LARGE FACTIONS OF ENEMY
}

\begin{abstract}
Author in this article continuous publications on the Battle of Stalingrad, revealing the role of army armored troops of Red Army during the breakthrough of the enemy's defense and surroundings of the 6th and 4th tank armies during the Stalingrad strategic offensive operation in the autumnwinter of 1942-1943, as the only one operation of the southwest, Don and Stalingrad fronts. The importance of groups of tanks of direct support of the infantry during the breakthrough of the enemy's defense and mobile units (tank and mechanized corps) during the completion of the breakthrough of the main enemy's defensive zone and the development of success inside of the enemy lines have been analyzed. The experience of the association of three tank corps for closer interaction under the general leadership of one of these commanders was singled out, which was the basis for the formation in the spring of 1943 of tank armies of a uniform composition.
\end{abstract}

Key words: Stalingrad strategic offensive operations; front line; tank corps.

Introduction

During the Second World War, in the offensive operations of the Red Army occupied an important place in the operations of the environment and the defeat of the surrounding grouping of the enemy. These operations are complex and demand from commanders, headquarters and personnel of diligent preparation, high organizational work of the headquarters and command and control units during the preparation and in the conduct of fighting (actions). The strategic offensive operation of Stalingrad occupies a special place in its scale and results, consisting of a set of front operations and operations of groups of fronts, which should be considered in stages.

The relevance of military and historical research of Stalingrad Strategic Offensive operations during the war imposed by Russian militarists in 2014 has theoretical and practical significance for the Armed Forces of Ukraine.

The level of military arts nowadays are not derogate from the experience gained during operations in World War II, particularly in Stalingrad Strategic Offensive, but rather confirms its viability. It requires constant development of military ideas aimed at improving the forms and methods of modern operations of the Armed Forces of Ukraine. And taking into account the experience of military experts will contribute to the expansion of their knowledge, outlook, development of creative thinking.

The historiography of the problem, which includes the question of the combat use of tank troops, is extremely broad and multifaceted. And Soviet historiography occupies a prominent position, and since the end of the twentieth century - Russian historiography.

Stalingrad's strategic offensive operation enriched the theory and practice of martial arts with new techniques and methods of armed struggle, as evidenced by numerous sources and scientific works, memoirs and popular literature.
In general, all the scientific works devoted to the course of the war are marked by the ideological stamps of the totalitarian era. The best of them, in our opinion, is "The History of the Second World War" in 12 volumes (published in 1973-1982), which contains a large scientific and historical material.

Despite ideological postulates and pre-programmed conclusions, the works of Soviet researchers of these years were marked by a significant factual and contained a lot of materials devoted to tank troops. The best of them are the works of G.A Deborin ${ }^{1}$, the collective monograph "The Second World War", edited by Lieutenant General S.P. Platonov, Major-General N.G. Pavlenko and Colonel I.V. Porotkin².

Lots of interesting information can be gleaned, bypassing obligatory ideological postulates and stamps, and from other Soviet scientific literature, where militarytheoretical views on the use of tank armies were considered, as well as the participation of tank units (associations) in campaigns of 1942-43 years $^{3}$.

\footnotetext{
1 Deborin, G.A. (1958). Second World War. Moscow, 234 p.

2 Platonov, S.P. (ed.), Pavlenko, N.G. (ed.) and Porotokin, I.V. (1958). Second World War of 1939-1945. Moscow, 1958. $654 \mathrm{p}$.

${ }^{3}$ Operatsii Sovetskikh Vooruzhennykh Sil v period korennogo pereloma $v$ khode Velikoy Otechestvennoy voyny (19 noyabrya 1942 g. - dekabr 1943 g.) (1958). Operatsii Sovetskikh Vooruzhennykh Sil v Velikoy Otechestvennoy voyne 1941-1945 gg. Vol. 2. Moscow: Voyenizdat, 518 p.; Korennoy perelom v khode Velikoy Otechestvennoy voyny (noyabr 1942 - dekabr 1943) (1961). Istoriya Velikoy Otechestvennoy voyny Sovetskogo Soyuza 1941-1945 gg. Vol. 3. Moscow: Voenizdat, 662 p.; Strokov, A.A. (1966). History of military art. Moscow: Voenizdat, 398 p.; Rotmistrov, P.A. (1963). History of military art. Vol.2. Moscow: Voenizdat, 720 p.; Kratkoye opisaniye pleneniya shtaba 6 -y nemetskoy armii vo glave s yeye komanduyushchim general-
} 
In general, studies of Soviet, especially contemporary Russian historians, helped to study the history of the development and use of tank troops ${ }^{4}$.

Question of the history of the use of tank armies has long been studied in Western Europe and the United States. Moreover, national schools not only make their peculiarities, but also maintain some tendentiousness ${ }^{5}$. German historiography has always been characterized by scrupulousness and attention to numbers and details. Actually, she managed to maintain objectivity and coverage of such a difficult topic as the Second World War, which provided a sufficient fact that allows us to understand the features of the use of tank armies in various campaigns and operations. Another feature of the German researchers were enthusiastic about the descriptions of the fighting of individual units, parts and compounds, especially the tank compounds, where it was possible to show the strong points of the Wehrmacht. Modern German historians are very restrained about the idea of a preventive war and are in no hurry to declare Stalin as an aggressor.

English historiography has become the most critical of the attitude of both - to their own and opponents. And although tank issues are second only (fleet occupies Britain's traditional championship). Not the most active among British military theorists of that time was Biezel Henry Liddell Hart. His main ideas relate to the mechanization and motorization of the army. B. Liddle Hart also survived the Second World War.

French military-theoretical thought was not far behind from English. French historians also did not justify their military-political leadership. The most prominent of them was Brigadier General Charles de Gaulle. He advocated for the mechanization and motorization of the army.

The works of American researchers, on the other hand, are rather superficial and contain whole series of minor inaccuracies. Their authors are hard to blame for deliberate engagement or supremacy, it is rather negligence for

feldmarshalom Paulyusom $\vee$ Stalingrade chastyami 64-y armii Donskogo fronta 31 yanvarya 1943 g. (1959). Voyenno-istoricheskii zhurnal, № 2. (In Russian)

${ }^{4}$ Samsonov, A.M. (1989). Stalingradskaya bitva (4 ed.). Moscow: Nauka, 604 p.; Rodin, A.G. (1958). Koltso okruzheniya. In: Bitva za Volgu. p. 134; Doerr, H. (1955). Der Feldzug nach Stalingrad. Versuch eines operative Uberblickes. Darmshtadt; Isayev, A.V. (2008). Stalingrad. Beyond the Volga there is no land for us. Moscow: Yauza, Eksmo, 448 p.

5 Tippelskirch, K. (2001). Istoriya vtoroy mirovoy voyny 19391945. Moscow: AST, 796 p.; Werth, A. (2001). Rossiya v voyne 1941-1945 gg. (Translation from English). Moscow: Voenizdat, 664 p.; Mellentin, F.V. (2005). Tank battles of 1939-1945: combat use of tanks in World War II (translat. from germ). Moscow: AST; SPb.: Polygon, 437 p.; Morzik, F. (1961). German Air force Airlift Operations. USAAF Historical division. P. 195; Manstein, E. von. (1955). Verlorene Siege. Bonn, p. 384; Haupt, Werner. (1997). Army Group North. The Wehrmacht in Russia 1941-1945. In: Schiffer Military History. Atlegen, 247 p.; Haupt, Werner. (1998). Army Group South. The Wehrmacht in Russia 1941-1945. In: Schiffer Military History. Atlegen, 259 p.; Fuller, J.F.C. (1948). The Second World War. London, 659 p.; Newton, S. (1994). German battle tactics on the Russian front. 1941-1945. In: Schiffer Military History. Atlegen, 333 p.; Busch, R. (2016). Survivors of Stalingrad: Eyewitness Accounts from the 6th Army, 1942-1943. London, 256 p.; Glantz, D. M. and Jonathan, M. (2017). House Stalingrad (Modern War Studies). Kansas, Abridged, 640 p.; Hellbeck, J., ed. (2015). Stalingrad: The City that Defeated the ThirdReich. Public Affairs, $512 \mathrm{p}$. details. In this respect, the publication of American authors ${ }^{6}$ can be opposed to the works of the German authors.

A respectable place in the complex of research sources for the development of military arts is taken by documents of personal origin: memoirs, memories ${ }^{7}$.

Archival materials ${ }^{8}$ are of special value for the study of military arts as regards the use of armored personnel carriers in the Stalingrad strategic offensive operation.

Ukrainian military historiography has only begun to consider these problems.

The complex of sources used in this study is divided into four groups: research of Soviet and contemporary Russian historians, works of military theorists of various national schools, memoirs and the fourth group includes archival collections.

During the analysis of the source base and historiography, views and ideas of military theorists of different countries regarding the role and order of the use of unions, unions of tank armies were taken into account.

Despite the peculiarities of the national historical schools, historiographical literature reflects various aspects of the combat use of tank troops.

The analysis of sources, scientific works, memoirs, the value of the Stalingrad strategic offensive operation allows using its experience in modern conditions in the Armed Forces of Ukraine, in the theory and practice of military arts.

\section{The purpose of the article}

On the basis of studying and analyzing of archival documents, memoirs and scientific literature about the Stalingrad strategic offensive operation, to identify the peculiarities of its preparation and conduct as operations on the surroundings, to identify the features and peculiarities of combat use of tank troops, to offer suggestions on the use of the experience in military theory and practice of modern military construction.

\section{Methods}

To achieve the purpose of the study, special methods of military-historical science and general scientific methods were used.

Due to the application of the historical method of research, they could identify the stages and with the maximum possible reliability to recreate the factors of the success of the tank troops in the Stalingrad strategic offensive operation, to clarify its results and consequences. Due to the use of the logical method, the factors that influenced the preparation and conduct of the operation

\footnotetext{
${ }^{6}$ Werth, A. (2001). Rossiya $v$ voyne 1941-1945 gg. (Translation from English). Moscow: Voenizdat, 664 p.; Young, S.P. and Lawford, J. (1970). History of the Britisch Army. New York, 189 p.; The Second World War. Two glances (G.-A. Jacobsen and A.Taylor) (1995). Moscow, 556 p.

${ }^{7}$ Vasilevsky, A.M. (1965). Nezabyvayemyye dni. Voyenno-istoricheskiy zhurnal. No. 10; Voronov, N. N. (1963). Na sluzhbe voyennoy. Moscow: Voenizdat, 434 p.; Wieder, I. (1965). Katastrofa na Volge. Vospominaniya ofitsera-razvedchika 6-y armii Paulyusa (Translat. from German). Moscow: Progress, p. 51-53; Adam, V. (1967). Trudnoye resheniye. (translat. from deuth). Moscow, p. 278.

${ }^{8}$ Central archives of the Ministry of Defence RF, f. 206, op. 262, d. 173, 189; Russian archive: Great Patriotic War: Orders of the People's Commissar of Defense of the USSR June 22, 1941 1942. T. 13 (2-2) (1997). Moscow: TERRA, 448 p.; Russian archive: Great Patriotic War: Supreme Command Rate: Documents and materials: 1942. T. 16 (5-2) (1996). Moscow: TERRA, 624 p.
} 
on the surrounding and the destruction of a large group of enemy were identified and revealed, the features of combat use of tank troops in the operation were identified and analyzed, the contribution of the acquired combat experience to the development of military art were revealed.

\section{Results}

Preparations for the transition to a counterattack began during the defensive battles near Stalingrad (Samsonov, 1989: 348).

The plan for the destruction of the German group on the Volga was the most important part of the plan of the winter campaign of $1942 / 43$, the strategic goal of which was the defeat of troops throughout the southern wing of the German army, the seizure of a strategic initiative and a breakthrough during the war in favor for the Soviet Union (Great Victory on the Volga, 1965: 219).

The idea of a counterattack was to smash the flanks of the main group of the enemy (Vol. 19, 1965, No. 10. p. 18) with powerful strikes from the bridgeheads Serafimovich, Kletsk and from the lake area south of Stalingrad and, developing an offensive in the directions that converge on Kalach, to surround and destroy the main forces of the enemy, who operating in the area of Stalingrad.

The fronts were tasked with operations. Fighting troops: to inflict a major blow from the bridgehead southwest front (SWF) of Serafimovich, defeat the enemy in the frontline and, by developing an offensive, by the end of the third day of offensive, enter the Kalacha region, where, together with the troops of the Stalingrad front (SF) and the Don front (DF), to complete the encirclement. Simultaneously part of the forces went out on the River Chir and create an active external front of the surrounding.

SF troops: strike from the area of the Sarpin lakes, break through the enemy's defense, and, developing an offensive against the Soviet, unit with the troops of the SWF, to surround and further in cooperation with other fronts, to destroy the enemy group. In order to secure its front group, it was necessary to part of the forces to step on Kotelnikovo and create an external front of the encirclement.

DF: strike two attacks in the direction of Vertyachy with the purpose of surroundings and defeat the enemy group near the bend of the Don. In the future, together with the troops of the SWF and the SF to destroy the surrounding group of the enemy (History of War and Military Art, 1970: 198).

At the same time, it was planned to inflict auxiliary strikes from the regions of Kachalinsk and Kletsk in the direction of Vertichy to cut down the enemy troops defending themselves in the bend of Don, from the Stalingrad group.

An significant role in the preparation of a counterattack in Stalingrad was played by the reserves of Supreme High Command General Headquarters (SHCGH), which consisting mainly of new formations (History of Military Art, 1966: 398).

But to determine the time of the transition to the offensive, the composition of the shock groups and the direction of their attacks on the German command was not successful (Fateful decision, 1958: 166; War.-Historical Journal, 1961, No. 4. S. 89). The uncertainty factor at this important stage of the struggle was of great importance in the course of further development.

The concentration of troops near Stalingrad and regrouping was carried out only at night with maintaining the strict measures of masking. General A.G Rodin, who commanded 26 tk and $5 \mathrm{TA}$, later wrote in his memoirs: "Unexpectedness was provided with all care and severity. When sending trains by rail, even their chiefs did not know the way of movement and station of destination. The concentration of parts after unloading took place only at night ... The task was known to a certain circle of people" (Rodin: 134).

The beginning of the offensive for the SWF and the DF was planned for November 19, and for the SF - by 20 . It was planned to simultaneously create the internal and external fronts of the encirclement. The inner front of the surrounding was created by tank, mechanized and cavalry corps. At the outer front there were rifle and cavalry divisions. Operative line up of the fronts was supposed to be in one echelon, and the general armies - in two echelons ${ }^{9}$

The strike groups had a significant advantage over their enemy in terms of manpower and technology in the direction of major strikes. As pointed out by K. Tippelskirh, the direction of the enemy's strikes was determined by the image of the front line: the left flank of the German group stretching nearly $300 \mathrm{~km}$ from Stalingrad to the bend of the Don in the district of Novaya Kalitva, and the short right flank, which was located particularly weak forces, began near Stalingrad and was lost in the Kalmyk steppe (Typelskirh, 2001: 349). And G. Djorr noted that "the command of the Soviet forces was skillful ... has set a breakthrough point so far from the flank of the German troops that the assistance of the German reserves did not come immediately" (Djerr, 1957: 66).

In all armies for the artillery preparation of the attack were involved artillery of other echelons. $45-\mathrm{mm}$ battalion and regimental, as well as $76-\mathrm{mm}$ regimental guns were planned to be used during the artillery training period for direct gunfire shooting, and with the onset of the attack, as infantry and tanks guards. For the support of infantry and tanks, it was planned to use part of the gun of diving artillery and anti-tank artillery regiments. In the armies, which had on the reinforcement of the cannon regiments of the SHCGH Reserve, armed groups of long-range action were created $^{10}$.

Fighting artillery was planned for periods: artillery training, artillery attack assault, and artillery support for infantry and tanks during combat at the depths of the enemy's defense (Operation SBAS, 1958: 33-44).

Much attention was paid to the air defense of the troops, for which the SWF and the DF had two, and the SF - one anti-aircraft artillery division and several anti-aircraft artillery units (History of Military Art, 1966: 402).

The main tasks of the aircraft were: the maintenance of conquered domination in the air; Coverage from the air strikes of the enemy of the strike groups of armies in the starting position for the offensive; suppression and destruction of the living force and fire equipment, as well as the destruction of defensive structures in the direction of major strikes of the armies during the breakthrough of the enemy's defense; direct support for the troops coming on offensive; air cover of mobile armies in the waiting areas and when they enter the breakthrough; suppressing the tactical and operational reserves of the enemy and

\footnotetext{
9 The bandwidth of the offensive of the fronts ranged from 85 to $180 \mathrm{~km}$, and the armies from 35 to $110 \mathrm{~km}$. The fronts broke the enemy's defense on two and three sections, and the army - on one, a width of 5 to $16 \mathrm{~km}$. The depth of operations for the fronts reached $60-140 \mathrm{~km}$, and the armies - from $50-60 \mathrm{~km}$ to $110-140 \mathrm{~km}$, the duration was 2-3 days, and the rate of offensive planned operations for the front reaches $60-140 \mathrm{~km}$, and armies - from 50$60 \mathrm{~km}$ to $110-140 \mathrm{~km}$, the duration was 2-3 days, and the pace of the offensive was planned $25-45 \mathrm{~km}$.

10 It consists of 3-4 gun regiments, approximately one for each division.
} 
obstructing their approach to breakthrough areas (Operation SBAS, 1958: 45).

The plan of aviation security provided for the beginning of the operation to strike night bombers on the combat orders of the enemy in the main lane of defense, and in the break-through period - the main forces of 17 PAs suppress hostile artillery positions, support points, KP and nodes in the direction of the main strike. With the beginning of the success of the aircraft, aviation was supposed to strike at enemy airfield and reserves, and part of the forces to support the attack of tank corps (History of Military Art, 1963: 202).

Fighting of tank and mechanized parts and units were planned according to the order of the People's Commissar of Defense (PCD) No. 325 from October 16, 1942 (Russian Archives, 1997: 334). Tank and mechanized corps were planned to be used as echelons of success ${ }^{11}$. They were intended to introduce into the breakthrough in the stripes of the armies advancing in the direction of the main strikes of the fronts with tasks: rapidly developing the offensive in the operational inside of the enemy's defense, defeating its immediate operational reserves, reach the rear of the main group of the enemy and surround it.

Individual tank brigades ${ }^{12}$ and battalions were added to infantry divisions to be used as group of tanks for direct infantry support (BPP). But due to insufficient number of Tank Army BPP ${ }^{13}$ as such, it was planned to use part of the forces of tank and mechanized corps. This weakened the impact of the last, but the army commanders were forced to take such measures because of the lack of tank units at their disposal (Operation SBAS, 1958: 46-47). The main task of the BPP tanks was to destroy enemy infantry. Typically, tanks were not allowed to engage with enemy tanks (except in cases of explicit advantage).

The skillful training of Soviet troops in a counterattack notices the A. Vert. "Preparing for an offensive was conducted with the highest secrecy. ... The Germans did not have a clear idea of the amount of equipment and troops delivered (mainly at night) to the area on the north of the Don and to the two main Soviet bridgeheads in the twist of the Don. ... the Germans did not have an idea of the power of the blow that was being prepared" (Vert, 2001: 353).

The coordination of the actions of all three fronts was assigned to the representative of the Stake ColonelGeneral O. M. Vasilevsky.

On the morning of November 19, after the 80-minute artillery training, an attack on the forces of the SWF and the DF went on the offensive.

A crushing fire inflicted heavy damage on the enemy. However, due to bad things, far from all targets were destroyed, especially on the flanks of the strike group of the SWF, where the enemy made the greatest resistance to the advancing troops (Samsonov, 1989: 375).

Unfavorable meteorological conditions did not allow aerial training. But the artillery fire was so powerful that the infantry connections of the first echelons of $5 \mathrm{TA}$ and $21 \mathrm{~A}$ SWF for 4-5 hours moved to a depth of 3-4 km, that means

\footnotetext{
11 The introduction of a breakthrough in tank shells was planned at 12 o'clock on the first day of the operation at a depth of $6-8 \mathrm{~km}$ from the front edge of the enemy's defense. The corps for the breakthrough was provided with an 8-10-km band from the calculation: $4-5 \mathrm{~km}$ for the column movement and $2-2.5 \mathrm{~km}$ for the provision of each flank of the strip for introduction into the breakthrough.

12 The width of the front of the offensive of the tank brigade ranged from 1.5 to $2 \mathrm{~km}$, and the tank regiment from 1 to $1.5 \mathrm{~km}$. 13 The density of TPBs in the breakthrough areas was 6-14 tanks per $1 \mathrm{~km}$ of front.
}

ISSN 1728-9343 (Print)

ISSN 2411-3093 (Online) they broke through the first position of the main band of the enemy's defense. In order to complete the breakthrough of the main lane of the enemy's defense at 12 o'clock at the breakthrough area 5 TA (commander-lieutenantgeneral P. L. Romanenko), the main forces of $1 \mathrm{tk}$ (commander- lieutenant -general P. L. Butkov) and 26 tk (commander-major-general O.G. Rodin), and at the breakthrough area $21 \mathrm{~A}$ (commander - Major General I. M. Chistyakov) - 4 tk (commander - Major-General A.G. Kravchenko). The massive attacks of large groups dazzled the enemy. He began to hurry backward. For 4-6 hrs. Tank corps, together with the rifle connections, completely completed the breakthrough of the tactical zone of the enemy's defense and entered the operational space (History of Military Art, 1966: 403-404).

On the first day of the offensive on November 19, the strike group of the SWF broke through the tactical zone of the enemy's defense and advanced units of tank corps moved forward inside for 20-35 km (Great Victory on the Volga, 1965: 262-264).

The output of the three tank corps at operating depth made a huge impact on the entire further course of the operation. He led to the partition of the $3 \mathrm{~A}$ (Romanian) opposing troops on isolated parts, which lost their interaction, which forced them to move away in different directions (History of Military Art, 1963: 208).

The next day, the Soviet troops, developing an offensive, struck at the operational reserves of the enemy. $1 \mathrm{tk}$, together with $8 \mathrm{kk}$, threw $22 \mathrm{td}$ (German) on south of Medvezhe. And $1 \mathrm{tk}$, developing the offensive, by the end of November, 22 went to the river Liska in $15-20 \mathrm{~km}$ north of its mouth. At the same time, 26 tons were dropped from the Perelazawsky region to the east of Part 1, td (Romanian) on November 20, and, continuing the offensive on the southeast, on November 22, pushed for Don in the Kalach region, seizing the crossing over the river. $4 \mathrm{pm}$ until evening on November 21 went to the Don to the north of Kalach.

Rifle units 5 TAs and $21 \mathrm{~A}$ the strikes of parts of their internal flanks captured the troops of two Romanian corps in the Raspynskaya region, and the remaining parts using the success of tank corps, quickly moved forward.

The SF troops started an offensive on November 20 in adverse weather conditions, which also ruled out aviation's actions. The armies went on the offensive alternately one after another, as the fog dissipated.

Connection 57 A (Commander-Major General, since January 19, 1943 - Lieutenant-General F.I. Tolbukhin), 51 A (commander-major-general M.I. Trufanov) and $64 \mathrm{~A}$ (commander-lieutenant-general M.S. Shumilov) on the first day broke the defense of the enemy and provided the introduction of a battle of 13 and 4 microns $(\mathrm{mc}), 4 \mathrm{kk}$, which by the end of the day moved to a depth of $10-16 \mathrm{~km}$.

After the breakthrough of the enemy's defense, the troops of all three fronts were able to develop an offensive at operational depths. Tank and mechanized corps moved up to $50-70 \mathrm{~km}$ a day (History of Wars and Military Art, 1970: 202).

The German command made attempts to prevent the connection of armored and mechanized buildings of the SWF and the SF. For this purpose, it sent to the Kalach and Malinovka districts 24 and 16 td and they managed to stop the Soviet offensive after they captured Kalach and a large bridgehead in the area and on the left bank of the Don.

Thus, on November 23, the surroundings of the enemy group in the area of Stalingrad were completed. On this day, the troops of the 64th and 57th SF securely took the border along the Chervlena River, blocking the ways to go south, and to the Don in the Kalach region, advanced

SKHID No. 2 (160) March-April 2019 
detachments of infantry divisions of $21 \mathrm{~A}$ SWF (Operation SBAS, 1958: 52).

Inside, there were 22 divisions $6 \mathrm{~A}$ and 4 TA units, 15 infantry divisions, 3 tank, 3 motorized, 1 cavalry, as well as 160 separate units. The total number reached 330 thousand people. Troops DF failed to cut off the enemy in the bend of Don, and the enemy partially went to the main group that operated directly near Stalingrad.

In addition to the $6 \mathrm{~A}$ and $6 \mathrm{~T}$ forces, the Soviet troops defeated the 3rd Romanian Army, 48 tk, which comprised the enemy's operational reserve, inflicted defeats 6 and 7 of the Romanians operating south of Stalingrad and were operationally subordinated to the commander of 4 TA (German) (Great Victory on the Volga, 1965: 283).

By the end of November 23 Soviet troops have created internal and external fronts. The total length of the outer front was: in the SWF band - $165 \mathrm{~km}$, and in the stretch of the SW - more than $100 \mathrm{~km}$. The maximum distance of the external front of the environment from the internal one was equal to the SWF - $100 \mathrm{~km}$, and at the SF - 75-80 km Minimum distance was within $15-20 \mathrm{~km}$. At the same time, the least distance from the outside was internal, it was in the most responsible directions ${ }^{14}$, from which the enemy was more likely to carry out a counterattack in order to release his surrounded group (Great Victory on the Volga, 1965: 283-284).

On November 24, an offensive against the Soviet troops began. Against the group of opponents surrounded at Stalingrad went on the offensive 21 (Russian archive, 1996: 415) ${ }^{15}, 65,24$ and 66 A DF, 62, 64 and 57 A SF. Fierce battles lasted until November 30 th. The area occupied by the surrounding group of the enemy was reduced to $1500 \mathrm{~km}^{2}$ (40 km from west to east and 30 to $40 \mathrm{~km}$ from north to south) (Operations SVS, 1958: 54).

A distinguishing feature of this stage of the counterattack was that tank and mechanized corps were aimed at creating the inner front of the encirclement. Cavalry corps and infantry divisions went to the rivers Chir and Aksai to create the outer front of the environment.

Soviet troops on the front of the Bokova to the lake. Sarpa (southern), over a distance of more than $300 \mathrm{~km}$, created a huge gap, covered only by the river Chir and Don with the remnants of the broken divisions of the enemy.

As a result of military actions, the enemy's defense was broken. The Strategic initiative went to the command of the Red Army. At the beginning of December 1942, a dense inner front of the environment was created around the grouping of the enemy.

During the development of a counterattack in the Battle of the Volga before the command of the Red Army, there was a need for a simultaneous solution to mutually opposite directions of two important tasks: to liquidate the surrounded enemy group in the rivers of the Don and the Volga and to develop further offensive on the Rostov direction (Russian Archive, 1996: 459).

The situation on the external front of the environment seriously aggravated. The enemy captured a small bridgehead on the left bank of the Don in the NizhniyChirsk region and held it firmly despite repeated attempts by the troops 5 TA to capture the bridgehead (History of Military Art, 1963: 212). In order to quickly release their surround troops 6 A and parts of forces 4 TA The German

\footnotetext{
14 Soviet, Lower Chirsk and Soviet, Askai.

15 Directive No. 170694 of 11/27/19426: 21 and in the composition: 4 and $26 \mathrm{tk}$; 51 vols, 293, 277, 63 and $96 \mathrm{sd}$; three tp and parts of the reinforcement of the army to transfer from the FPF to the DF. $3 \mathrm{gv}$ kk without tank regiments to leave as part of the NRF.
}

command hastily created two groups: one of the district Tormosin (about 17 divisions) and the second in the district Kotelnikovo (13 divisions), which became part of the newly formed group of armies "Don "(Commander - Field Marshal Erich von Manstein).

Taking into account the current situation, the SHCGH Stage made changes to the previously approved plan Saturn (Russian Archives, 1996: 466) and limited itself to Operation Small Saturn: instead of an offensive on Rostov it was decided to strike a powerful blow in the south-eastern direction on Tacin, Morozovsky, defeat the Italian and Romanian troops who were defending Don and Chir, as well as the Hollidt operational group and moving the outer front of the ambience to the west of the confederated forces at $150-200 \mathrm{~km}$.

Soviet SHCGH made a decision with the forces of $1 \mathrm{~A}$, 3 guards A and 5 TA SWF and 6 A Voronezh Front in order to develop counterattack and disrupt the plans of the enemy $A$ and defeat the 8th Italian and the remains of the 3rd Romanian Army.

According to the plan of the front commander, the defeat of the enemy on the Don and Cher River was supposed to be carried out by strikes of the forces of 1 guards $A$ from the Upper district. Mamon in the direction of Tacin and 3 guards A from the eastern part of. Bokovskaya - on Morozovsky. At the same time, part of the forces of the adjacent flanks of these armies was planned to develop an offensive in the directions converging on Bokovsky, in order to surround and destroy the troops of the 8th Italian Army. Provision of a shock group of 1 guards $A$ from the west he was assigned to $6 \mathrm{~A}$, who was given the task to step in the direction of Kantemirovka, Millerovo (History of Military Art, 1963: 214).

The attack on the SWF strike groups started simultaneously on the morning of December 16 after an hour and a half of artillery attack preparations. In the fierce twoday battles, the tank corps, together with the infantry, broke through the enemy's defenses, and by the morning of December 18 they went to the southern coast of Bogucharka river. Until the end of the day, the troops of 1 guards $\mathrm{A}$ and $6 \mathrm{~A}$ expanded the front of the breakthrough to $60 \mathrm{~km}$ and completed the breakthrough in the band of 3 guards $A$ at the front of the width of up to $20 \mathrm{~km}$ (Operations SVS, 1958: 65).

The actions of tank corps after their release into the operational space took the nature of the rapid pursuit of enemy troops, who were retreating. The greatest pace of persecution was developed by $24 \mathrm{tk}$. In five days they moved on $240 \mathrm{~km}$ and on the morning of December 24 they seized the station Tacin. The attack was so rapid and sudden that the enemy did not have time to pick up airplanes. In total, it was captured at the airfield and in echelons at the railway station of 350 planes. Thus, the troops of 24 tk crossed the more important railway communication linking the group of armies "Don" with the rear, which deprived the German command not only to complete the concentration of their brakes group, but also to provide supplies with the necessary material resources. Under the prevailing German command it was compelled to refuse the use of the Germans group to release its surrounded troops in the inter-rivers Don and the Volga and in a hurry to send them against the attacking troops. But the enemy succeeded at the turn north of Tacins, Morozovsky to prevent a breakthrough $25 \mathrm{tk}$. $24 \mathrm{tk}$ was in the surroundings. Within five days, the corps repulsed the enemy's attacks, which sought to seize the Tacinsk (History of Military Art, 1963: 216).

Until December 24, an enemy group was liquidated, consisting of three Italian and one German infantry divisions in the north-east of Alekseevo-Lozovsky region. 
The development of the offensive by Soviet troops threatened to cover the right flank of the group of GermanHungarian troops in the Voronezh direction and, which was particularly dangerous for the enemy, threatened the reach of the left flank and the rear of its group in the areas of Tormosin and Kotelnikovo.

Until December 30, troops of the SWF, destroyed the enemies surrounded by the rear of the group, stood at the turn: Nov. Kalitva, Markovka, Chertkovo, Voloshino, north of Millerovo, llyinka, Skorsir, Chernyshkovsky (Operations of the SWS, 1958: 66-67)

The success of the operation, as well as in the first stage of counterattack, played a decisive role in tank and mechanized corps $^{16}$.

For closer interaction 24, 25 tk and 1 guards during the battle for Tacinsk and Morozovsky, during the battle, they were united under the general command of the commander of 24 tk (Major-General V. M. Badanov). This experience was justified and was the basis for the formation in the spring of 1943, tank armies of a homogeneous composition.

From 12 to 30 December, the Kotelnikovsky offensive operation was conducted by the SF troops. The 51A troops resisted parts and connections of the right wing of the Goth armies group, whose goal was to join forces surrounded by troops, which in turn were supposed to strike a counter strike.

The main forces of the left flank of the Goth armies group, concentrated in the area of Tormosin and intended to strike at Stalingrad, but were transferred to Morozovsky and Tacinsk, where they were involved in the battle with the troops of the SWF. There was also thrown from Kotelnikovsky direction and $6 \mathrm{td}$. Thus, by December 24, the plan to attack the enemy in order to release his troops surrounded by the Stalingrad region was sabotaged.

By December 23, on the Kotelnikovsky direction, concentrated 2 guards $A$ from 7 tk and unfolded on the Mishkov River from Shabalinsky to Kapkinsky. Left-handed $51 \mathrm{~A}$ in the five sd and three microns. More to the right 2 guards A were deployed one cd of 5 Defence A and 4 kk.

On the morning of December 24, the group of the left wing of the SF went on the offensive to defeat the opposing group (Operations SVS, 1958: 67-68).

The main strike inflicted 2 guards $A$ in the direction of Kotelnikovo from the north, $51 \mathrm{~A}$ - from the north east, and its $13 \mathrm{mk}$ and 3 guards $\mathrm{mk}$ broke through the front of the 4th Romanian army to deep cover the enemy's group from the south.

Within three days of the battles, the rifle divisions 2 guards $A$ and $51 \mathrm{~A}$ together with the 2 guards $\mathrm{mk}$ and $7 \mathrm{tk}$ entered in the battle were consistently broke through the defenses of the German group on the Myshkov AksayYesaulovsky rivers, advanced to a depth of $40 \mathrm{~km}$ and proceeded to cover the enemy's flanks retreating.

At the same time, the troops of the left wing, $51 \mathrm{~A}$, together with $13 \mathrm{mk}$ and 3 guards mk defeated the opposing parts of the 4th Romanian army, and, pursuing them, went to Shabalin and the Zavitne (History of Military Art, 1963: 220)

Until December 31, the SF troops went to Verkhnaya, Rubizhne, Tormosin, Zhukovsky, Komissarovsky, Gluboky. During the operation on the Kotelnikovsky direction, the 4th Romanian army was finally defeated, and the 4th German Tank Army was thrown at 200-250 km away from Stalingrad, to the Zimyvinki area with great losses. The remnants of the units of the Army group "Don" departed in

$1617,18,24,25$ tank and $1 \mathrm{gv}$. mechanized, which had in its structure 750 cars.

ISSN 1728-9343 (Print)

ISSN 2411-3093 (Online) the southern direction, to the turn of the Manich River (Samsonov, 1989: 467).

Thus, the second German group, which had the task of helping its surrounded troops, was defeated. And hence the fate of the surrounded group was solved in advance. This was understood by the German SHCGH. F. Millentin noted that "... The battle on the banks of this river led to the Third Reich crisis, put an end to Hitler's hopes for the creation of an empire and became a decisive link in the chain of events leading to the defeat of Germany" (Mellentin, 2005: 242).

In terms of improving the organizational forms and combat use of armored troops, the experience of uniting under the general leadership of several tank and mechanized corps are of certain interest. It was taken into account when creating tank armies.

By the end of December 1942, the threat of a bleeding blow from the outside had been eliminated. The territory occupied by the surrounding troops, shortened significantly, and almost fired by the fire of Soviet artillery. In the course of the fighting, the German command completely spent all its reserves.

The calculations of the German command for the organization of the uninterrupted delivery of troops surrounded by air failed. With loss at the end of December, as a result of Operation Small Saturn in most airfields, the shoulder of air transportation increased significantly (Isaev, 2008: 389-390). This transformed the operation of supplying $6 \mathrm{~A}$ Paulus into the beating of the transport aircraft Luftwaffe (the Germans from November 24, 1942 to January 31, 1943, lost 488 planes and about 1,000 people flying warehouse) (Morzik F., 1961: 195).

Elimination of the surrounding group of the enemy was assigned to the troops of the DP, acting on the internal front of the environment (Voronov, 1963: 300).

The vision of the operation envisaged eliminating the surrounded group of the enemy in a consistent manner: to cut off and destroy the enemy's forces in the western part, and then, in the southern part of the ring, after a rapid blow to dissociate the enemy troops, which remained in two parts, and destroy them separately (History of the Great Patriotic War, 1961: 56)

Three armies $(65,24$ and 21$)$ were assigned to destroy the surrounding group in the western part (the main blow), in the southern part two armies (57 and 64). In the northeastern part acted $66 \mathrm{~A}$, and in the eastern part of the city 62 A. Operational line up DF was in one echelon (History of Military Art, 1963: 222).

In the direction of the main strike, $33 \%$ of rifle divisions, $50 \%$ of artillery, $57 \%$ of the Guards mortar and $75 \%$ of the tank regiments were concentrated. This allowed us to create a significant density of forces and means 19 . The combat and numerical strength of the DF on January 10 , 1943 was: the personnel - 281158 people; mortar 6,247 units; Field guns - 1,702 (CAMD RF, vol. 206, op. 262, pp. 189, p. 102).

January 8, 1943, the Soviet command brought the ultimatum with the proposal to surrender the German troops, surrounded at Stalingrad. But Colonel-General F. Paulus rejected the ultimatum after talks with $\mathrm{OKX}$ and on the orders of Hitler.

On the morning of January 10, the troops of the DF went on a decisive offensive to destroy the surrounding enemy group. By the end of the day, on a number of sites, the enemy's defense had been broken to a depth of $6-8 \mathrm{~km}$.

Already the first days of the offensive turned into heavy losses for the DF tank troops. At 22:00 on January 12, the presence of tanks in tank parts was 120 units. (CAMD RF, 206, op. 262, issue 173, pp. 13). And at 22.00 on January 9,

SKHID No. 2 (160) March-April 2019 
there were 264 (CAMD RF, fax 206, op. 262, issue 173, pp. 11).

The troops of the DF, having conducted a regrouping of forces during January 13 and 14 , resumed the offensive on the morning of January 15 and until the middle of the day the defense was overthrown. Remains 6 A began to retreat to the ruins of Stalingrad. By January 16, the territory of the neighborhood of $6 \mathrm{~A}$ was reduced to the size of less than a third of the original. But the success was not easy. The losses of troops of the DF during the first five days of the offensive amounted to 22043 (excluding 64 A) (CAMD RF, No. 206, op. 262, No. 189, pp. 131).

After defeating part of the adversary, the troops of the DF until the end of January 17 went to the Great Rossoshka, Gonchar, Voroponovo, where they met the desperate resistance of the enemy on the old Soviet fortifications on the approaches to the city. On the strengthening of the armored forces of the front on January 16 , 48th separate Guards Tank Regiment was sent on Mk.IV tanks "Churchill".

The German group persistently maintained the strengthening of the internal defense zone, but after the crushing strikes of the Soviet artillery, the enemy's defense was broken and on January 25, Soviet troops broke into Stalingrad from the west. By the end of January 26, troops 21 and $62 \mathrm{~A}$ united in the area of Mamayev Kurgan, and dismembered the enemy's group into two parts: the southern part was clamped in the central part of the city and the northern region, surrounded by the Tractor Plant and the Barricade Factory (Operation SAS, 1958: 77-78). From January 27 , battles on the elimination of dismembered groups began. At the same time, the enemy still did not stop the resistance. In the southern sector, a particularly stubborn struggle went beyond the elevator, the bakery, the Stalingrad II station, the Dagoria church and the buildings adjacent to them. The troops of 64,57 and $21 \mathrm{~A}$ from the southwest and northwest compressed the circle surrounding the southern group of the enemy. On the night of January 28th to 29th, the left flank connection of $64 \mathrm{~A}$, overcoming the river Tsaritsa, went to the central part of the city. The enemy was demoralized. "Imprisonment has taken a massive character. In just three days, from 27 to 29.1.43, parts of 64 A captured 15 thousand soldiers and officers" (War.-Historical Journal, 1959, No. 2. p. 88).

By January 31, the resistance of the enemy troopers in the southern part of the city was finally broken and capitulated. Headquarters $6 \mathrm{~A}$ headed by Commander General-Field Marshal F. Paulus on that day were captured.

An enemy group of $11 \mathrm{ak}$, surrounded by the northern part of the city, continued to fight. For its defeat, an unprecedented density was created - up to 300 guns and mortars per $1 \mathrm{~km}$ of front. It was almost 5 times more than during the transition to a counterattack (History of the Second World War, 1961: 62). Having not sustained the fire strike of such force, 11 ak also capitulated. And on Feb. 2,1943 , the historic victory at Stalingrad ended.

In total, during the Operation "Ring", more than 2,500 officers and 24 generals of $6 \mathrm{~A}$, more than 91 thousand soldiers and officers of the Wehrmacht were taken into captivity. The trophies of the Soviet troops from January 10 to February 2, 1943, according to the report of the headquarters of the DF were 5762 guns, 1312 mortars, 12701 machine guns, 156987 guns, 10722 guns, 744 aircraft, 1666 tanks, 261 armored vehicles, 80438 motor vehicles, 10679 motorcycles, 240 tractors, 571 tractor, 3 armored trains, etc. (Isaev, 2008: 419).

\section{Discussion}

For the first time in the domestic historiography, on the basis of a comparative analysis of archival documents, memoirs, general and special works of both warring parties on the Stalingrad strategic offensive operation, the author made an attempt to reveal its course, results, consequences and peculiarities of the combat use of the tank army of the mixed warehouse and tank, mechanized corps in the operation on the encirclement. As a result of the study, a number of conclusions were drawn different from the previous conclusions of the predecessors, all the new ones were analyzed in terms of operative art and tactics during its conduct regarding the use of tank armies; an objective assessment was made of the significance of the Stalingrad Strategic Offensive Operation for the Development of Military Arts in Operations with the surrounding and destruction of large groups of the enemy.

New to the study is that the author attempted to assess the role of the Stalingrad strategic offensive operation, not only in the development of Soviet military art, but also in the art of war opposing the warring side. Particular attention is drawn to the actions of the German command to create a stable defense of the surrounding troops, ensuring high moral and psychological stability of the personnel in extremely difficult conditions, decisive attempts to release the surrounded group, the organization of measures for the comprehensive provision of the surrounded group.

The obtained results of the research can be used for further military-historical scientific developments, research works on the problems of the Second World War, the study of the issues of the development of military arts in the use of large tank associations. The provisions and conclusions of scientific work can be introduced into the educational process of cadets and students of the Second World War of Ukraine through their use in conducting studies on military-historical disciplines, as well as the basic material in contemporary military-theoretical discussions about the role and principles of the use of tank armies in modern the stage of development of the Armed Forces of Ukraine. Their study by military experts will contribute to the expansion of the horizons, the development of creative thinking.

Promising areas of further research can be: a comprehensive study of the development of Soviet military art in conducting operations on the enemy's environment on the territory of Ukraine, studying the experience of the German command to release and withdraw from the environment of its troops.

\section{Conclusion}

The author made a theoretical generalization and solved a scientific objective to determine the role, place, characteristics and features of the use of the Red Army armored troops in the Stalingrad Strategic Offensive as one of the outstanding operations on the encirclement during the Second World War and to develop recommendations for using the experience in modern warfare. theory and practice.

Despite the large number of historical and special works devoted to this operation, a number of issues remain unresolved for the time being: the particular features of the use of tank armies in operations on the environment under extremely difficult operational conditions. These issues require a thorough historical study involving the source base of both warring parties.

The author used well-known general scientific and special methods of historical research, among which the main place belongs to historical and logical methods, analysis, comparison, generalization, statistical method, system approach.

The article analyzes the conditions and factors that exerted a significant influence on the preparation, course and results of the Stalingrad Strategic Offensive Operation, 
on the use of the tank army of mixed warehouses and tank and mechanized buildings. Armored troop contributed the main strike force in the operation.

Operative art in the counterattack at Stalingrad was characterized by a large scale of front and army offensive operations conducted in accordance with the strategic plan.

Operative line up of the fronts was in one echelon, and the armies were usually in two echelons. The armies advancing towards the main strike had in their second echelon, except for 1-2 infantry divisions, 1-3 tank (mechanized) corps.

Armored and mechanized troops were used in accordance with the requirements of the order of the PCD No. 325 of October 16, 1942. Tank brigades and regiments were used as direct support infantry tanks. But the density of tanks was still not enough for a rapid breakthrough in advance prepared enemy defense.

In a counterattack at Stalingrad, tank armies of the mixed composition, tank and mechanized corps were successfully used. Tank and mechanized hulls were used to develop success in the direction of the main strike and operations at operational depths. At the first stage of the counterattack, they carried out the surroundings of a large group of opponents. At the same time, the overwhelming number was involved in completing the breakthrough of the tactical zone of the enemy's defense, which significantly weakened the forces of mobile units before the start of their main task.

Inclusion of tank and mechanized units was supported by all of the first echelon artillery and by long range army group. To secure the actions of tank and mechanized corps in the enemy lines each one was accompanied by onetwo anti-tank units and one of anti-air units.

Thus, battle experience gained in the battle on Volga served as a basis for future development of military excellence of Red Army. Based on this experience they learned the art of surrounding with consecutive annihilation of enemy troops.

\section{REFERENCES}

Adam, V. (1967). Trudnoye resheniye. (translat. from deuth). Moscow. (In Russian).

Busch, R. (2016). Survivors of Stalingrad: Eyewitness Accounts from the 6th Army, 1942-1943. London, 256 p. (In Enlish).

Doerr, H. (1955). Der Feldzug nach Stalingrad. Versuch eines operative Uberblickes. Darmshtadt. (In Germ)

Dopros voyennykh prestupnikov (1961). Voyenno-istoricheskii zhurnal. No. 4. p. 89 (In Russian).

Fuller, J. F. C. (1948). The Second World War. London, 659 p. (In English)

Glantz, D. M. and Jonathan, M. (2017). House Stalingrad (Modern War Studies). Kansas, Abridged, 640 p. (In English).

Haupt, Werner. (1997). Army Group North. The Wehrmacht in Russia 1941-1945. In: Schiffer Military History. Atlegen, 247 p. (In English).

Haupt, Werner. (1998). Army Group South. The Wehrmacht in Russia 1941-1945. In: Schiffer Military History. Atlegen, 259 p. (In English).

Hellbeck, J., ed. (2015). Stalingrad: The City that Defeated the Third Reich. Public Affairs, 512 p. (In English)

History of Wars and Military Art (1970). Moscow: Voenizdat,

560 p. (In Russian)

Isayev, A. V. (2008). Stalingrad. Beyond the Volga there is no land for us. Moscow: Yauza, Eksmo, 448 p. (In Russian).

Korennoy perelom $v$ khode Velikoy Otechestvennoy voyny (noyabr 1942 - dekabr 1943) (1961). Istoriya Velikoy Otechestvennoy voyny Sovetskogo Soyuza 1941-1945 gg. Vol. 3. Moscow: Voenizdat, 662 p. (In Russian).
Kratkoye opisaniye pleneniya shtaba 6-y nemetskoy armii vo glave s yeye komanduyushchim general-feldmarshalom Paulyusom v Stalingrade chastyami 64-y armii Donskogo fronta 31 yanvarya 1943 g. (1959). Voyenno-istoricheskii zhurnal, № 2. (In Russian). Manstein, E. von. (1955). Verlorene Siege. Bonn, p. 384. (In Germ).

Mellentin, F. V. (2005). Tank battles of 1939-1945: combat use of tanks in World War II (translat. from germ). Moscow: AST; $\mathrm{SPb}$.: Polygon, $437 \mathrm{p}$. (In Russian).

Morzik, F. (1961). German Air force Airlift Operations. USAAF Historical division. P. 195. (In English).

Newton, S. (1994). German battle tactics on the Russian front 1941-1945. In: Schiffer Military History. Atlegen, 333 p. (In English).

Operatsii Sovetskikh Vooruzhennykh Sil v period korennogo pereloma $v$ khode Velikoy Otechestvennoy voyny (19 noyabrya 1942 g. - dekabr 1943 g.) (1958). Operatsii Sovetskikh Vooruzhennykh Sil v Velikoy Otechestvennoy voyne 1941-1945 gg. Vol. 2. Moscow: Voyenizdat, 518 p. (In Russian).

Prikazy narodnogo komissara oborony SSSR 22 iyunya $1941 \mathrm{~g}$. 1942 g. (1997). Russkiy arkhiv: Velikaya Otechestvennaya: Vol. 13 (2-2). Moscow: TERRA, 448 p. (In Russian).

Rodin, A. G. (1958). Koltso okruzheniya. In: Bitva za Volgu. p. 134. (In Russian).

Rokossovsky, K. K., ed. (1965). Velikaya pobeda na Volge. Moscow: Voenizdat, 528 p. (In Russian).

Rotmistrov, P. A. (1963). History of military art. Vol.2. Moscow: Voenizdat, 720 p. (In Russian).

Samsonov, A. M. (1989). Stalingradskaya bitva (4 ed.). Moscow: Nauka, 604 p. (In Russian).

Stavka VGK: Dokumenty i materialy: 1942 god. (1996). Russkiy arkhiv: Velikaya Otechestvennaya: Vol. 16 (5-2). Moscow: TERRA, 624 p. (In Russian).

Strokov, A. A. (1966). History of military art. Moscow: Voenizdat, 398 p. (In Russian).

Tippelskirch, K. (2001). Istoriya vtoroy mirovoy voyny 19391945. Moscow: AST, 796 p. (In Russian).

Vasilevsky, A. M. (1965). Nezabyvayemyye dni. Voyennoistoricheskiy zhurnal. No. 10. (In Russian).

Voronov, N. N. (1963). Na sluzhbe voyennoy. Moscow: Voenizdat, 434 p. (In Russian).

Werth, A. (2001). Rossiya v voyne 1941-1945 gg. (Translation from English). Moscow: Voenizdat, 664 p. (In Russian).

Wieder, I. (1965). Katastrofa na Volge. Vospominaniya ofitserarazvedchika 6-y armii Paulyusa (Translat. from German). Moscow: Progress, p. 51-53. (In Russian).

Zhilin, P. (1958). Rokovyye resheniya. Moscow: Voenizdat, P. 166. (In Russian).

\section{LIST OF REFERENCE LINKS}

Busch R. Survivors of Stalingrad: Eyewitness Accounts from the 6th Army, 1942-1943. London, 2016. 256 p.

Doerr H. Der Feldzug nach Stalingrad. Versuch eines operativen Überblickes. Darmstadt, 1955.

Fuller J. F. C. The Second World War. London, 1948. 659 p.

Newton S. German battle tactics on the Russian front. 1941-

1945. Schiffer Military History. Atlegen, 1994. 333 p.

Glantz D. M., Jonathan M. House Stalingrad (Modern War Studies). Kansas, Abridged, 2017. 640 p.

Stalingrad: The City that Defeated the ThirdReich / ed. J. Hellbeck. Public Affairs, 2015. $512 \mathrm{p}$.

Haupt Werner. Army Group North. The Wehrmacht in Russia 1941-1945. Schiffer Military History. Atlegen, 1997. 247 p. Haupt Werner. Army Group South. The Wehrmacht in Russia

1941-1945. Schiffer Military History. Atlegen, 1998. 259 p. Manstein E. von. Verlorene Siege. Bonn, 1955. s. 384. Morzik F. German Air force Airlift Operations. USAAF Historical division. 1961. P. 195

Адам В. Трудное решение / пер. с нем. Москва, 1967.

Василевский А. М. Незабываемые дни. Военно-исторический журнал. 1965, № 10. 
Великая победа на Волге / под ред. Маршала Советского Союза К. К. Рокоссовского. Москва: Воениздат, 1965. 528 с.

Верт А. Россия в войне 1941-1945 гг. / авторизованный перевод с английского. Москва: Воениздат, 2001. 664 с.

Видер И. Катастрофа на Волге. Воспоминания офицераразведчика 6-й армии Паулюса / пер. с нем. А. В. Лебедева и Н. С. Португалова. Москва: Прогресс, 1965. С. 51-53.

Воронов Н. Н. На службе военной. Москва: Воениздат, 1963. $434 \mathrm{c}$.

Допрос военных преступников. Воен.-ист. журн. 1961. № 4. С. 89 .

Исаев А. В. Сталинград. За Волгой для нас земли нет. Москва: Яуза, Эксмо, 2008. 448 с.

История Великой Отечественной войны Советского Союза 1941-1945 гг. Т. 3. Коренной перелом в ходе Великой Отечественной войны (ноябрь 1942 г. - декабрь 1943 г.). Москва: Воениздат, 1961. 662 с.

История военного искусства / под общ. ред. доктора исторических наук, профессора, полковника А. А. Строкова. Москва: Воениздат, 1966. 398 с.

История военного искусства. Т 2. / под общ. ред. доктора исторических наук, профессора, Главного маршала бронетанковых войск П. А. Ротмистрова. Москва: Воениздат, 1963. $720 \mathrm{c}$.

История войн и военного искусства. Учебник для высших военных учебных заведений. Москва: Воениздат, 1970. $560 \mathrm{c}$.

История Второй мировой войны 1939-1945 гг.: В 12 т. / Институт военной истории МО СССР, Институт марксизмаленинизма при ЦК КПСС, Институт всеобщей истории АН
СССР, Институт истории СССР АН СССР. Москва: Воениздат, 1973-1982.

Краткое описание пленения штаба 6-й немецкой армии во главе с ее командующим генерал-фельдмаршалом Паулюсом в Сталинграде частями 64-й армии Донского фронта 31 января 1943 г. Воен.-ист. журн. 1959. № 2.

Меллентин Ф.В.Танковые сражения 1939-1945 гг.: боевое применение танков во Второй мировой войне / пер. с нем. Москва: АСТ; СПб.: Полигон, 2005. 437 с.

Операции Советских Вооруженных Сил в Великой Отечественной войне 1941-1945 гг. т. 2. Операции Советских Вооруженных Сил в период коренного перелома в ходе Великой Отечественной войны (19 ноября 1942 г. - декабрь 1943 г.). Москва: Воениздат, 1958. 518 с.

Родин А. Г. гвардии генерал-лейтенант. Кольцо окружения. Битва за Волгу. С. 134

Роковые решения / под ред. доктора исторических наук, полковника П. А. Жилина. Москва: Воениздат, 1958. С. 166.

Русский архив: Великая Отечественная: Приказы народного комиссара обороны СССР 22 июня 1941 г. 1942 г. Т. 13 (22). Москва: ТЕРPA, 1997. 448 с.

Русский архив: Великая Отечественная: Ставка ВГК: Документы и материалы: 1942 год. Т. 16(5-2). Москва: ТЕРРА, 1996. 624 c.

Самсонов А. М. Сталинградская битва. 4-е изд., испр. и доп. Москва: Наука, 1989. 604 с.

Типпельскирх К. История второй мировой войны 19391945. Москва: АСТ, 2001. 796 с.

ЦАМО РФ, ф. 206, оп. 262, спр. 173

ЦАМО РФ, фр. 206, оп. 262, спр. 189

Кривизюк Леонід,

Науковий иентр Начіональної академії сухопутних військ

імені гетьмана Петра Сагайдачного (м. Львів, Украӥна)

e-mail:leonid.krivizuk@gmail.com,ORCID 0000-0001-9094-4061

\section{СТАЛІНГРАДСЬКА СТРАТЕГІЧНА НАСТУПАЛЬНА ОПЕРАЦІЯ (19.11.1942 - 02.02.1943): ФАКТОРИ УСПІХУ ТАНКОВИХ ВІЙСЬК З ОТОЧЕННЯ І ЗНИЩЕННЯ КРУПНОГОУГРУПОВАННЯ ПРОТИВНИКА}

Автором здійснено теоретичне узагальнення і вирішено наукову задачу з визначення ролі, місця, характерних рис і особливостей застосування танкових військ Червоної армії у Сталінградській стратегічній наступальній операції як однієї з видатних операцій на оточення в роки Другої світової війни та вироблення рекомендацій щодо використання дослідженого досвіду у сучасній військовій теорії та практиці. Незважаючи на велику кількість історичних і спеціальних праць, присвячених цій операції, на сьогодні до кінця не вирішеними залишаються ціла низка питань: особливості застосування танкових військ в операції на оточення за вкрай складних оперативних умов. Автором були застосовані відомі загальнонаукові та спеціальні методи історичного дослідження, серед яких головне місце належить історичному та логічному методам, аналізу, порівнянню, узагальненню, статистичному методу, системному підходу. У статті проаналізовані умови і фактори, які справили суттєвий вплив на підготовку, хід і результати Сталінградської стратегічної наступальної операції, на застосування у ній танкової армії змішаного складу і танкових, механізованих корпусів. Уперше у вітчизняній історіографії на основі порівняльного аналізу архівних документів, мемуарів, загальних та спеціальних праць обох воюючих сторін щодо Сталінградської стратегічної наступальної операції здійснено спробу з максимально можливою достовірністю розкрити її хід, результати, наслідки та особливості бойового застосування танкової армії змішаного складу і танкових, механізованих корпусів в операції на оточення. Зроблена спроба оцінити роль Сталінградської стратегічної наступальної операції не тільки в розвитку радянського воєнного мистецтва, а й воєнного мистецтва протилежної воюючої сторони. Особливо акцентовано на заходах німецького командування по створенню стійкої оборони оточених військ, забезпеченню високої морально-психологічної стійкості особового складу за надзвичайно складних умов, рішучі спроби деблокування оточеного угруповання, організації заходів всебічного забезпечення оточеного угруповання.

Ключові слова: Сталінградська стратегічна наступальна операція; фрронт; танковий корпус.

(C) Kryvyzyuk Leonid

Надійшла до редакції: 06.03.2019

Прийнята до друку: 10.04.2019 